\title{
触覚ロボットの制御方式†
}

\author{
武安清雄・猪山忠男・霜村来爾・後藤達生 \\ 日立製作所中央研究所 国分寺市東恋厅窪 1-280 \\ (昭和 47 年 4 月 15 日 受付)
}

\section{Control Algorithm for Tactile Controlled Hand}

\author{
Kiyoo Takeyasu, Tadao Inoyama, Raiji Shimomura and Tatsuo Gotō \\ (Central Research Laboratory of Hitachi Ltd., Kokubunji) \\ (Received April 15, 1972)
}

\begin{abstract}
This paper describes a robot equipped with a computerized tactile member named "HI-T-HAND" that can feel the forms of various objects and their positions and, according to the command, pack the objects compactly one by one into a given pallet.

The major functions of the robot are to, (1) feel for scattered objects, (2) recognize the form and the position of an object for holding it firmly, (3) change the posture of an object to facilitate subsequent operations, (4) select the best methods of shifting an object toward and positioning it in a pallet and, (5) push an object, for tight packaging, against the inner wall of a pallet or against other objects already thus arranged.
\end{abstract}

\section{1. 緒言}

生産ラインに括ける工業用ロボットの導入は, 労働 人口の減少を反映して活発化している. しかし生産形 態そのものが多品種中小量生産へ移行する傾向がある ことから, ある程度の判断能力と, 触覚や視覚などの 認識能力を持つ, フレキシビリティの高い知能機械へ の関心が高まっている.

人工知能ロボットに関しては，MIT，スタンフォー ド大学あるいは SRI など米国の各研究機関での研究 が著名であり ${ }^{1)}$ ，わが国でも電子技術総合研究所や日 立中央研究所に和いて視覚認識を有するロボットシス テムへのアプローチが進められている ${ }^{2,3)}$. とくに触 覚認識に関しては国内での研究が活発であり，電子技 術総合研究所に特ける物体の探索や把握への利用2), 早大に拈ける義手感覚としての利用 ${ }^{4)}$, あるいは中央

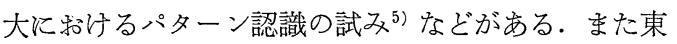
工大では触覚信号をPID 処理することにより, 作業 条件に応じてロボットの応答特性を変化させる試みが 行なわれており ${ }^{6}$, 東大では力感覚を連続量としてフ ィードバックすることによってロボットに双動性を与

$†$ 電気学会東京支部大会で一部発表 (昭 46・11)
え,クランクの回転やピンの押しこみ作業などを可能 にした7).

われわれは，多品種の製品を対象とした箱詰作業や， 段ボール箱のパレットへの積上作業の自動化に必要な 触覚による認識制御アルゴリズムの開発を目的として 触覚ロボット “HI-T-HAND” (Hitachi Tactile Controlled Hand）を完成した.このロボットは箱の中に 执ける物体群の配置パターン特よび箱詰順序を命令さ れることにより，触覚により適宜物体の位置姿勢など を判断しながら作業手順を決定し，これらの物体をす きまなく詰め込んでいくことができる，本論文では， とくにオンオフ的な触覚牱よび力感覚をるらいた，物 体の適応的なつかみ機能ならびに，あてがい，押しつ けによる位置決め機能の制御アルゴリズムについて述 ベる.

\section{2. 触覚ロボットの構成と機能}

\section{$2 \cdot 1$ 箱詰作業に関連したロボットの機能}

試作した触覚ロボットは，Fig. 1 に示すように判 断処理機構亡しての電子計算機之, 外部環境の検出手 段としての触覚扣よび力感覚を有するハンドリング装 置とで構成されて和り, 人間から与えられる命令を理 


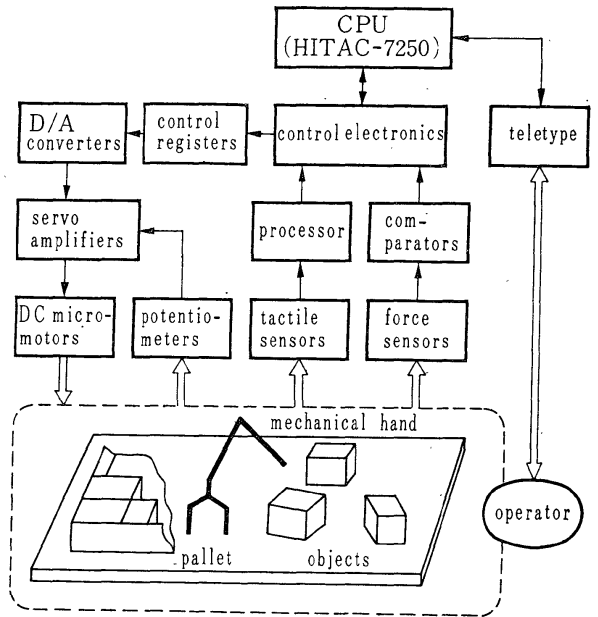

Fig. 1 Schematic diagram of tactile-controlled-hand

解することによって適切な作業手順を判断し，対象物 体の状況に応じて作業を進めていく能力がある。箱詰 作業に必要なロボットの判断能力は, Fig. 2 亿示し

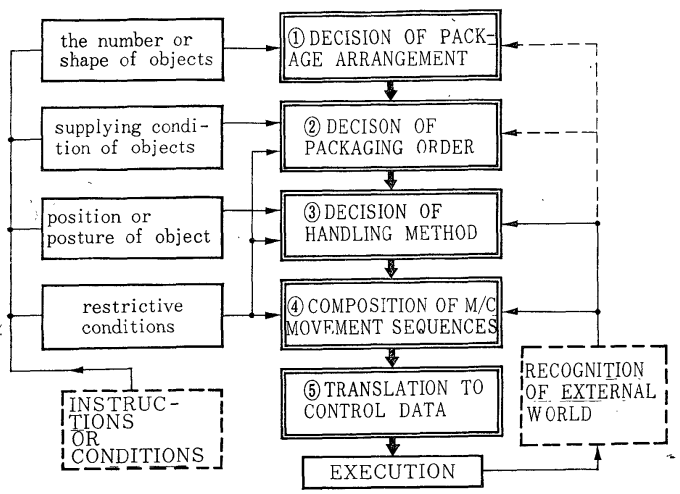

Fig. 2 Decision making for packaging operation たように，与光られる命令のレベルによって異なる。 人工知能開発の側面から言光ば, (1)p(2)の処理段階, すなわち箱の中の物体配置や箱詰順序の決定の問題に 興味が多い。乙かし実用化の観点からすれば，現状で はこのような決定はまだ人間が行なった方がよく，む しろ与兄られ状沉に応じた作業手順の決定をロボッ 卜自身に行なわせるべきだと考えている。このよらな 意味からわれわれは，箱の中の物体の配置は命令とし てロボットに与光(3以降の判断の処理を行なわせるこ とを目的とした。またこのロボットは視覚要素を持た ないので，広範囲の作業台上を探索することをさける ため，箱や供給物体の存在する領域はあるていど指定 することにしている．このよらに必要最小限の命令が 与えられると，ロボットはまず目的とする物体を手探 りで見つけてその姿勢を調べ，後続する作業に都合の
よい位置を判断してつかみ，箱の中の所定位置に適切 な方向から物体をあてがって置いたり，必要な方向か ら押しつけて位置決めするなど，希望の箱詰パターン を命令するだけで，ロボット自身が状況に応じた作業： 手順の判断を行なってコンパクトな箱詰作業を進めて いくことができる.

\section{$2 \cdot 2$ ハードウエアの構成}

ハンドリング装置は手首をでの 全長 $610 \mathrm{~mm}$ の 関 節形で 6 つの運動の自由度を持ち, 半径ならびに高さ 約 $500 \mathrm{~mm}$ の作業空間を有する. つか及機構は平行 2 指で,つか及幅約 $100 \mathrm{~mm}$ の開閉動作を行なうこと ができる.各関節の駆動はマイクロモータ(出力 $2 \mathrm{~W}$ ) とポテンショメータを利用した直流サーボ機構で行な う。移動速度は基幹部の 3 軸が約 $90 \%$ ，先端部の 3 軸が約 $180^{\circ}$ /s である．駆動モータをできるだけ駆動 軸付近に配置することによって，全体として小形軽量。 高効率な設計とした。

感覚器としては, 接触覚, 圧覚, すべり感覚ならび に力感覚を持つが，すべてオンオフ的に信号を検出し ている. Fig. 3 亿指先に扔汀る触覚の配置構造を示.

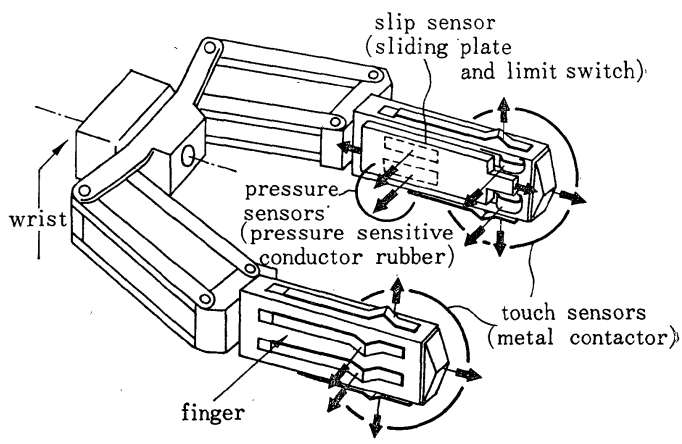

Fig. 3 Distribution of tactile sensors around finger surfaces

す.指の周囲には接触圧の小さい（約 $30 \mathrm{gr}$ ) 金属接 点を用いた 12 個の接触検出素子が市り，指の内面に は導電性ゴムを利用した圧覚検出素子を 4 個配置し 100 500 gr の範囲内で 2 段階程度の圧力変化を検出 することができる，さらに指の内面全体が指の基部に 対して相対的に約 $2 \mathrm{~mm}$ 移動できる構造とすること そよって，一方问性のすべり感覚として利用している. また各関節に生じるサーボ偏差を力感覚として利用 し7)，一定のしきい值を設定することにより反力の方 向を含めた 3 值の検出々力が取り出せる。いっぽう指 の開閉操作は，計算機からの指令によって位置制御モ ードと力制御モードの切換觉が可能である.

\section{$2 \cdot 3$ ソフトゥェアの構成}

ソフトウェアに融通性を与光，小容量化することを 
目的として, ロボットの動作処理機能のレベルに応じ てプログラムを分類し， Fig. 4 に示すようなハイア ラキ構成としている．まず基本動作プログラムは指の 開閉動作や手の直線移動など，各種の作業に含まれる 8 種類の手の基本的な動作要素を抽出したるのである。 これらは Fig. 2 の(4)の段階に対応したレベルのプロ グラムであり，座標変換やデータ転送など，より基本 的なサブルーチンで構成されている，次に物体をつか む，対象面にあてがうなど作業として意味を持つ最小 単位を 10 種類の単位作業プログラムとして, 基本動 作プログラムを組合わせて構成する．これらは Fig. 2 の(3に対応したレベルのプログラムである。箱詰など 一連の目的を持つ作業は単位作業の連続であり, 命令

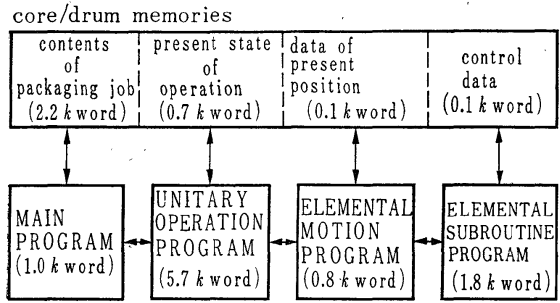

Fig. 4 Schematic diagram of software system

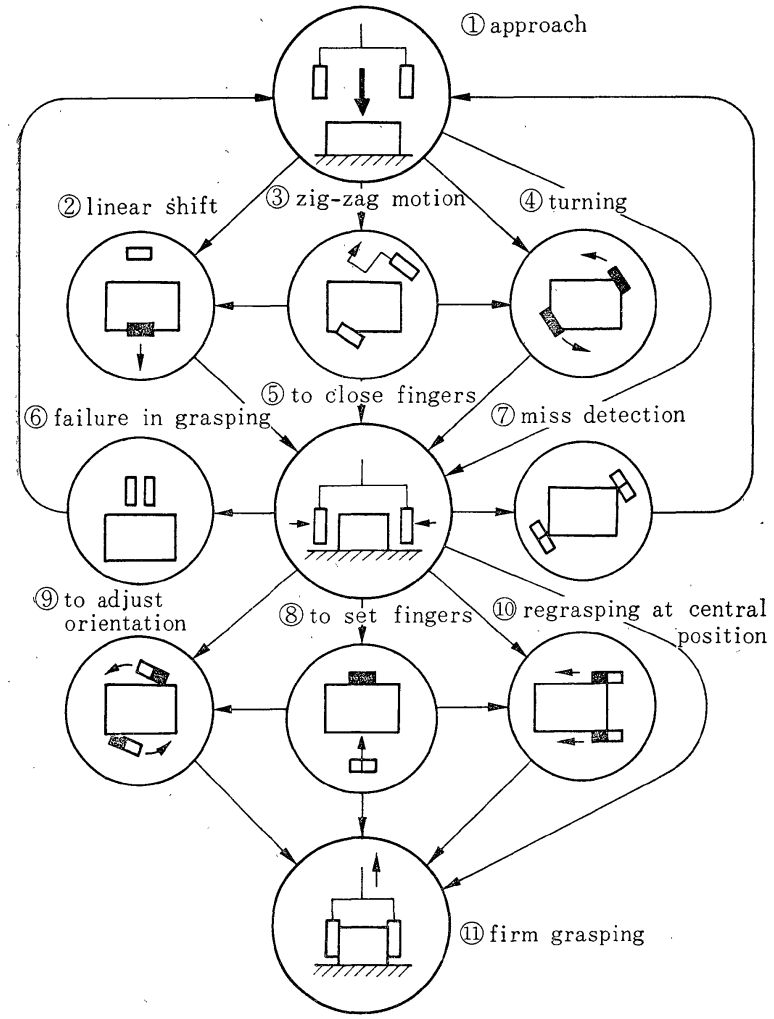

Fig. 5 Algorithm for grasping function
解読や作業管理を行ならメインプログラムによってコ ントロールされる．各プログラムには個々のレベルに 応じた入出力データが必要であり，これらをコアやド ラムのデータエリアに格納する．このように機能単位 ごとにプログラムを分割することにより，全体として の容量を少なくすると同時に，プログラムの部分修正 あるいは新しい機能の付加をできるようにした。

\section{3. 触覚適応制御のアルゴリズム}

\section{$3 \cdot 1$ つかみ機能}

物体の姿勢の判定，物体の適切な方向からのつか及 あげなど，一連の目的を持つ作業を実行するためには， まず物体の位置を確認し，その姿勢に応じて手の位置 を修正し，安定な状態で物体をつか屯制御が要求され る.このような適応的なつかみ動作を手と物体の相対 位置関係に応じて整理ずる Fig. 5 のようになる.

Fig. 5 飞特いて (1)から (5) は指の先端の触覚検出パタ ーンに対応して，物体を捕捉可能な状態に手の位置を 修正する動作であり，(5)加ら价は指の内面の触覚検出 パターンに応じて，物体を動かすことなく指の方向を 一致させ，できるだけ物体の中心位置をつかむ動作で ある. (3)，(6)あるいは(7)のように触覚汇よる検出が不 可能な条件に対しては, 力感覚のバックアップ により，触筧検出が可能な位置をたは方向に手 を移動する・たとえば(7)の状態では指に生じる 力感覚によって物体をつかんでいることは検出 できるが，手と物体の相対位置関係を具体的に 把握することは不可能である。乙たがって指を いったん開いたのち，じゃっかん方向を变えた 状態でつか及動作をやりな特す，このように個 数の限られた触覚装置に基づいて生じる問題点 を，力感覚によるバックアップ処理で実用的な 解決を行なっている. Fig. 5 の (5)から (11) に示 したつか久動作を例炕とると，指の内面の 4 個 の触覚の検出パターンに応じて, 両指を一定值 閉じる動作, 手首を一定值直線移動する動作, 手首を一定値回転する動作，のいずれかが実行 される.こ机らの対応関係は Fig. 6 に示した 之和りである. 4 個の触覚のうち 3 個以上がオ ンとなったときを安定なつかみ状態とみなして 動作を打切る.

このような適応的なつかみ動作は，冶具など に拘束された物体を無理なくつか及出す場合に 必要な機能であり，委た物体の寸法をより正確 に測定することができるので姿勢形状の判定ミ スを防ぐことにもなる。 


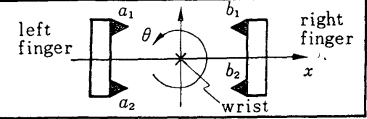

35

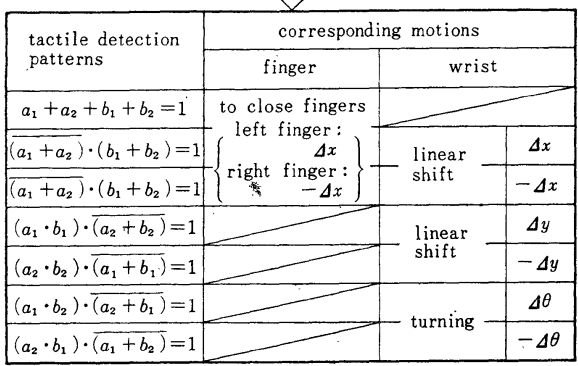

Fig. 6 Grasping motions corresponding to tactile detection patterns

\section{$3 \cdot 2$ 位置決め機能}

箱詰作業に扮活る位置決めは，常に箱の内面あるい はすでに箱詰された物体の表面で形成される 3 直交面 を対象として行なわれる.すなわち Fig. 7 に0 とし て示した無拘束状態から，物体を任意の 1 面にまずあ てがったのち 3 面に拘束された 30 の状態に物体を移 行することで種々の動作手順がある．物体を指ではさ むつかみ機構では, 最終的な位置決め状態を得るため に，物体をいったん手ばなしたあと，対象面に押しつ ける動作が必要である。

このような位置決め作業を行なら場合に，触覚の配 置や個数に制限があり，力感覚をオンオフ信号として 利用できるようにするために，対象面に対する手先の

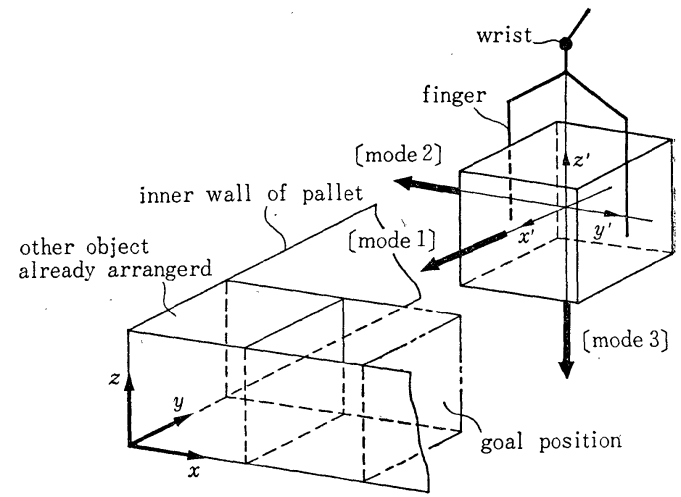

Fig. 8 Movement direction for positioning

姿勢や移動方向に一定の制限を与えている.まず Fig. 8 に示したように手先の移動方向として次の 3 種類を 設定する.

（i） mode 1: 手先を基準として前後方向（Fig. 8 の $x^{\prime}$ 軸方向) の移動.

(ii) mode 2: 手先を基準と乙て左右方向 (Fig. 8 の $y^{\prime}$ 軸方向) の移動.

(iii) mode 3 : 手先を基準として上下方向 (Fig: 8 の $z^{\prime}$ 軸方向) の移動.

さらに，これらの各移動方向を箱の内面を基準とし た直交座標系 $x, y, z$ 軸のいずれかに平行となる状 態に限定する. この結果, 位置決め動作にさいして手 先の触覚が常に対象面にほぼ対向した状態になり, 検 出ミスを少なくできると同時に，各移動モードに対応 する触覚や力感覚が自動的に定ま り，接触状態の判定など情報処理 を簡単化できる。

位置決めのための対象面への接 近動作は，各対象面から一定距離 の位置に設定されたバイアス点か ら，対象面を越光て設定された接 近動作打切り点に向って各移動モ ードを組合わせて実行される、こ の場合 Fig. 9 亿示したように作 業空間を最小移動単位量でメッシ ュ状に分割することにより，接近 動作の実行を移動モードの実行回 数で処理する方法をとっている. 移動モードの組合わせ方で接近軌 道が変化し, Fig. 9 の (1) に示し たように各移動モードを順次その 全回数を実行する方法もあるが， 比較的小さな対象面に対しても物

Fig. 7 Positioning states transition in packaging 


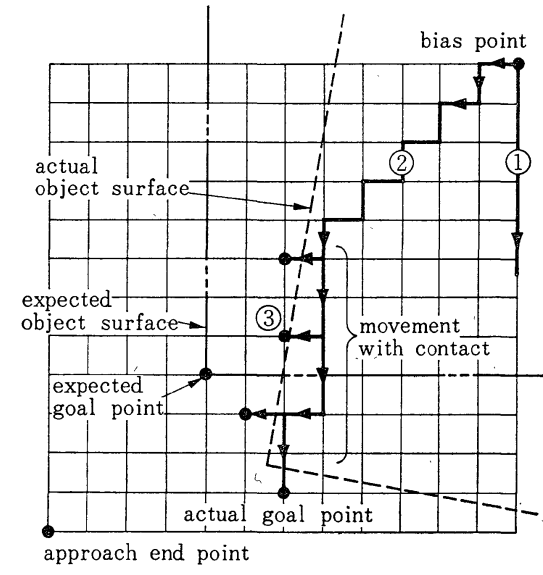

Fig. 9 Approach movement for positioning

体を確実にあてが觉るように，特に指定しない限り(2) のように各移動モードを 1 回ずつ交互に実行する方法 をとっている。

対象面との接触を生じた移動モードはその時点で実 行を打切って，以後は他の移動モードたけを実行する。 この場合, 対象面との接触状態を一定に保つため, Fig. 9 の (3)に示したように対象面をチェックするた めの動作を間欠的深行する。

あてがい動作は次のいずれかの場合泈了し，物体 を手ばなす。

（1）すべての移動モードの方向に接触を生じた場 合.したがって物体を手ばなした状態は Fig. 7 の (32) になる。

（2）モード3の方向に接触を生じた場合. したが って物体を手ばなして状態は, Fig. 7 の (10), (20), (24) たは(32のいずれかになる。

後者は物体を対象面の近くに置く作業に相当する。 特に指定がないとさは前者が穾行される．

物体を手ばなしたあとは，次章に述べるように，あ てがい作業の結果に応じて優先方向を考光ながら物体 を対象面仠しつけて位置決めを行なら。オンオフ的 な力感覚で対象面への押しつけ状態を確認可能にする ため, 反力をともなら移動が連続した時点で反力が消 滅するまで後退する。これらの実行回数が等しいとき は物体が対象面に押しつけられたと判定して作業を打 切る. 反力が消滅するまでの後退回数の方が少ないと きは物体が拘束されず移動していると判断して押しつ 许作業を続行する。押しつけによる位置決め作業では, 物体が手に固定されていないため, 物体が対象面とほ ぼ面接触状態となりコンパクトな箱詰が可能である.

\section{4. 箱詰作業実験}

$4 \cdot 1$ 箱詰命令の処理亡作業手順決定

箱詰作業の命令は Fig. 10 に示したよらに箱の内

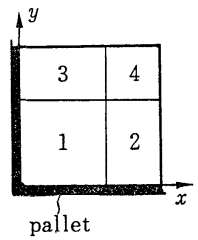

\begin{tabular}{|c|c|c|c|c|c|c|}
\hline \multirow{2}{*}{$\begin{array}{c}\text { number } \\
\text { of } \\
\text { object }\end{array}$} & \multicolumn{2}{|c|}{$\begin{array}{c}\text { adjoiningobjects } \\
\text { in pallet }\end{array}$} & \multicolumn{3}{|c|}{ size } \\
and \\
\cline { 2 - 7 } & $x$ & $y$ & $z$ & $x$ & $y$ & $z$ \\
\hline 1 & 0 & 0 & 0 & 50 & 50 & 50 \\
\hline 2 & 1 & 0 & 0 & 35 & 50 & 50 \\
\hline 3 & 0 & 1 & 0 & 50 & 35 & 50 \\
\hline 4 & 3 & 2 & 0 & 35 & 35 & 50 \\
\hline$\vdots$ & $\vdots$ & $\vdots$ & $\vdots$ & $\vdots$ & $\vdots$ & $\vdots$ \\
\hline
\end{tabular}

Fig. 10 Example of the packaging instruction

面を基準とした物体の接触関係と各物体の寸法姿勢で 与光る.この命令内容はメインプログラムによって個 々の物体の位置と接触面の方向を示すデータに変換さ れる. 箱詰作業はこれらのデータをもとに，つかみ， あてがい，押しつけ作業の順序で実行される。

まずつか及作業は, 対象物体を手探りでさがして姿 勢を判定し，あてがい作業に都合のよい状態牎体を

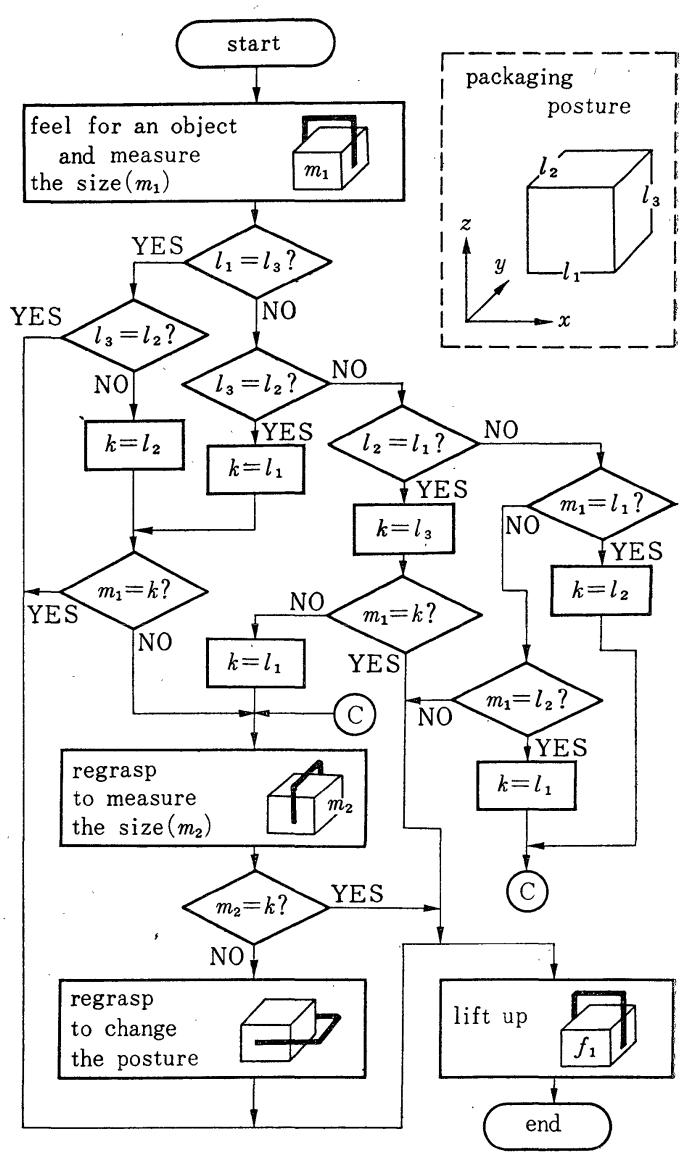

Fig. 11 Procedure of grasping operation 


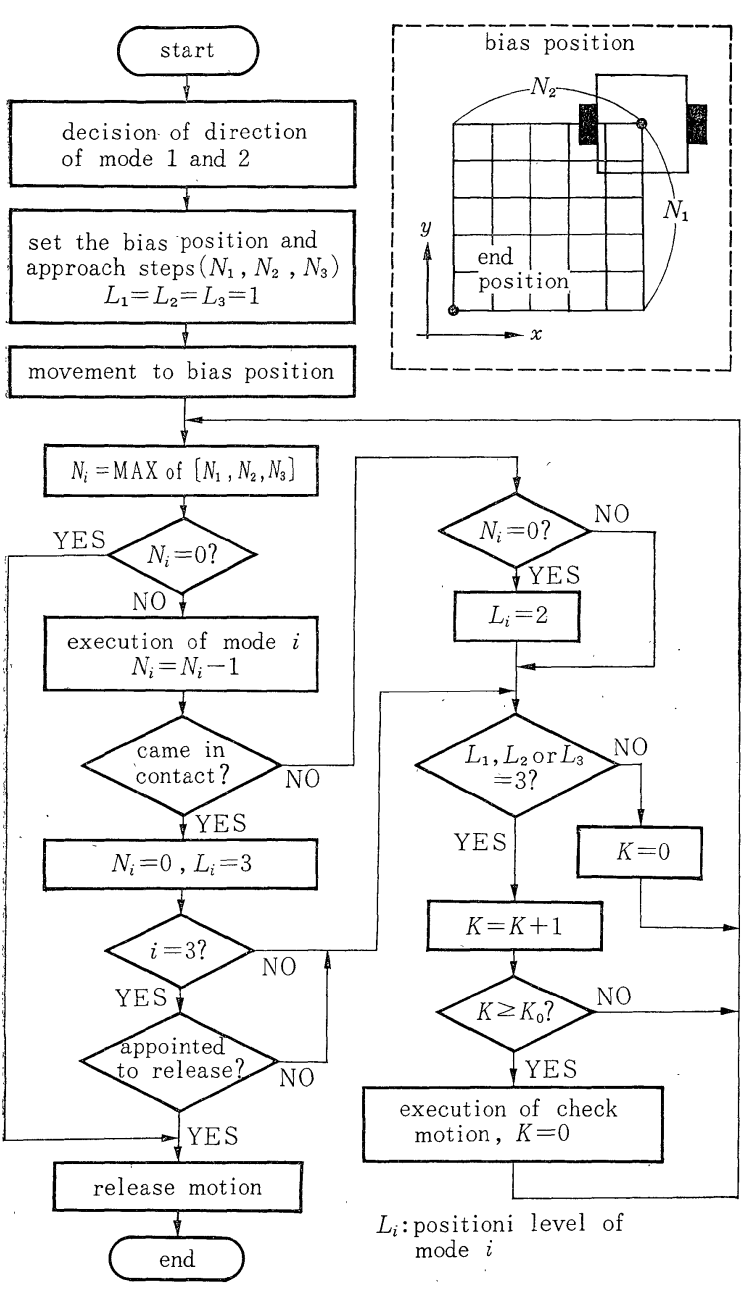

Fig. 12 Procedure of positioning by press motion

つかみ上げることを目的として Fig. 11 の手順で実 行される.上述された箱詰命令によって対象物体の寸 法形状は与えられているので，物体の寸法測定結果と 照合して姿勢を判定する.物体の形状拈よび姿勢によ って判定に要するつかみ回数は異なり, 適宜ロボット 自身が必要な動作を判断して行なう。

Fig. 12 とあてがい作業の実行手順を示す。これら の作業では各移動モード方向の位置決め状態を，また 位置決めが完了せず，移動モードの実行残回数がある 場合（レベル1），接触を生じないまま残回数が零と なった場合（レベル2），位置決めが完了し実行が打 切られた場合（レベル 3） と分類表示して，作業手順 処理に利用している。あてがい作業に括惊る移動モー ド 1，2の方は，つか及作業の結果で異なり，これ に応じてバイアス点と手先姿勢が定まるあてがい作 業の種類，あるいは箱や物体のつか夕位置のばらつき に応じて，物体が手ばなされた段階での各モードの位

置決め状態は上記の 3 種類のレベルのいずれかであ る. これらの位置決めレベルに応じて, Fig. 13 に 示したように適切な手順で押しつけ動作を実行する。 モード 1 放よび 2 のレベルが 1 のときは対象面に押 しつけず一定值だけ押しこんだのち他方向を押すこ

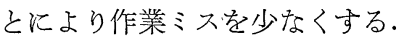

\section{$4 \cdot 2$ 箱詰作業実験例}

Fig. 10 亿示した箱詰命令を与兄た場合の作業実 験結果を Fig. 14 亿示す。A は指の下端の触覚を 利用して物体を手探りでさがす状態を示す，Bは各 物体のつか反動作を示している。（i ）は立方体で 姿勢判定が不要な場合であり，位置ずれ学指の内面 の触覚で検出しながら物体を動かさないようにつか む.（ii）は手先に対し物体の方向がずれている場 合であり，指の内面を物体に合わせてつかむ．本物 体の場合このつかみ動作だけで姿勢判定が可能であ り，乙かもあてがい動作に必要なつかみ条件を満た しているので，そのままつかみ上げる。（iii）は （ii）と同形状の物体であるが，姿勢判定に 2 回の つかみ動作が必要な場合で䓎る. 1 回目の動作で中 心位置をつか反な特しているのがわかる（iv）で は2 回のつか反動作によって姿勢を判定した結果,

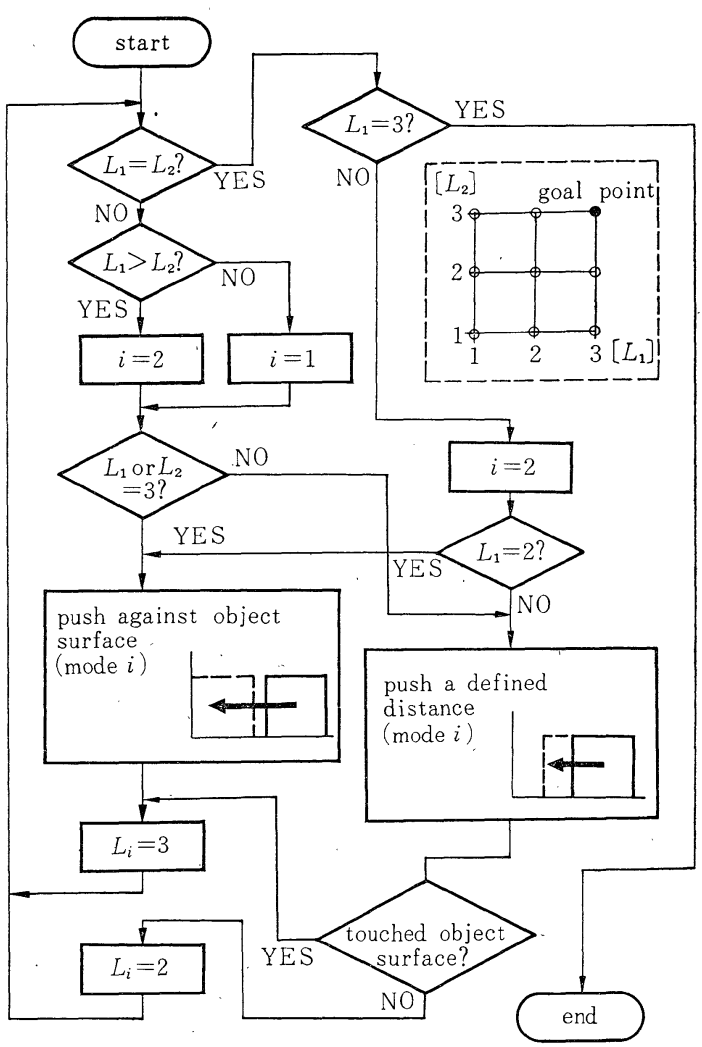

Fig. 13 Procedure of positioning by push motion 


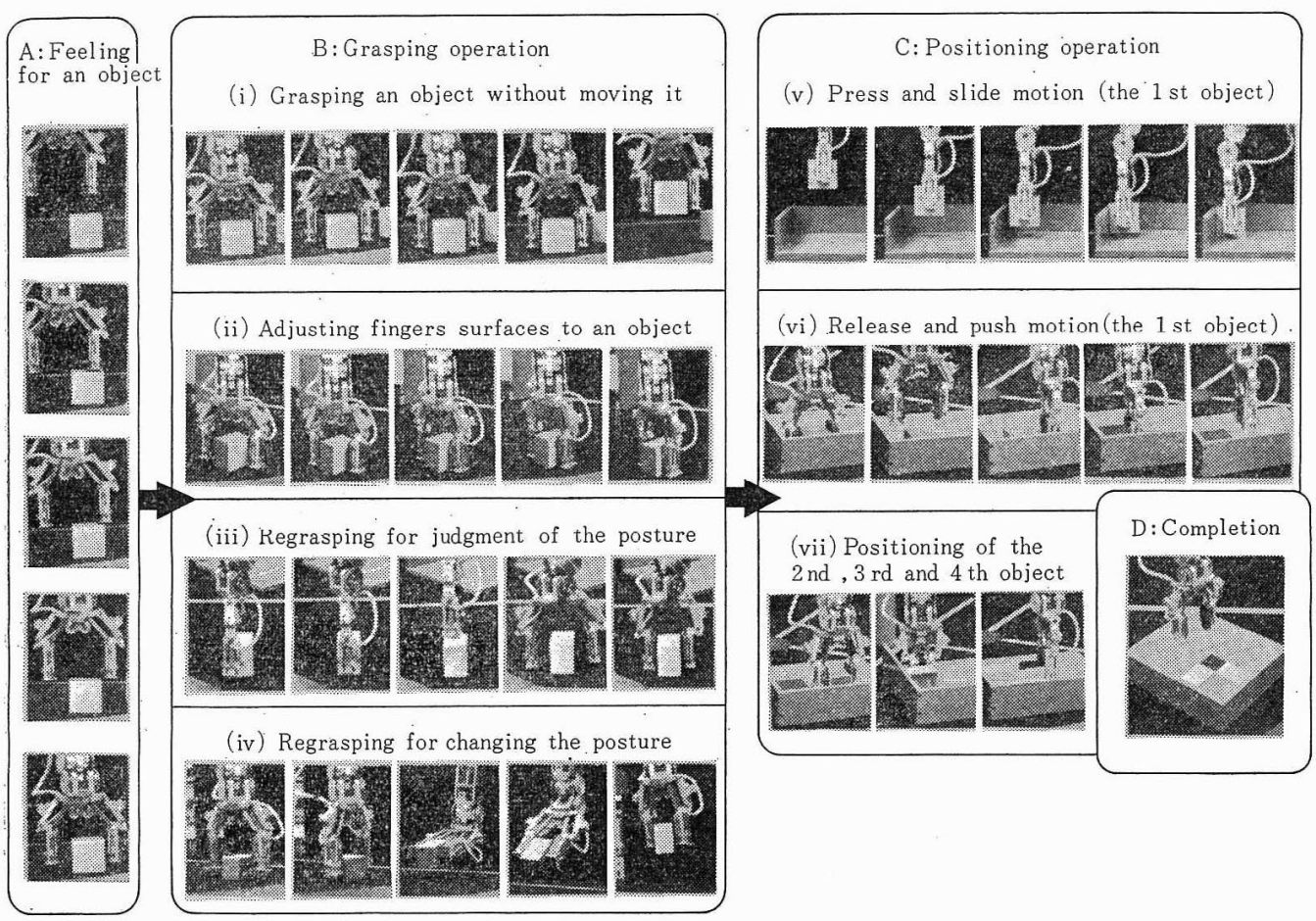

Fig. 14 Example of packaging operation

物体の姿勢変更を必要とする場合である。

Fig. 14 の Cは箱への物体の位置決め動作を示して いる（v）は岕てがいによる位置決め動作例であり， （vi）洞じ物体そ手ばなし，押しつけ動作で位置決 めする状態を示す．あてがい動作でモード1の方向に はすでに位置決めを完了しているのでモード2の方向 に押しつけ作業を実行する。隹様にしてあてがい, 押しつけ作業を適宜行ないながら4個の物体を指定さ れた配置にすきまなく箱詰している。なお，これらの 作業に要する時間は触觉割込制御を主体とするつかみ 作業の場合で約 $3 \mathrm{~s}$ である. 位置決め作業ではサーザ 偏差を力感覚として用いるため移動モード 1 回の㝝行 に約 $100 \mathrm{~ms}$ を要し，あてがい，押しつけを含めた作 業時間は 15〜〜20 s となっている. 作業速度向上の ためには割达制御が可能な力感覚検出方式の開発が必 要である。

\section{5. 縮言}

手さぐりで種々な形状寸法の物体の姿㭞位置などを 認識し，箱の隅からりぎりぎそすさまなく，命令され た配置でつめて行くことができる触覚ロボットを開発 した.このロボットの持つ主な触覚動作機能ふ,

（1）触覚によって物体位置党探索し，一定範国内 にある物体を探してつかむ。

（2）物体の置かれている姿勢に指の方向，位置を 合わせて，物体を動かさずに安定につかさ。

（3）物体の寸法を測定し，形状や姿勢を判定する.

（4）物体を対象面にあてがい，拉るいはあてがっ た李京移動して位置決文する。
（5）物体を対象面に押しつけて位置決めする. などである.さらにマクロな命令をもとに視覚機能な しに箱詰を实行するための判断処理機能をこれらの触 覚機能との関連で開発し, 知能ロボット実用化への 1 つの方向を示した．まな触覚と力感覚を相互にバック アッブ処理させることにより, 個数の限られた検出器 で作業を満足に実行できるよらにしたこと，あるいは 検出器の出力をオンオフ信号として利用でさるように 制御アルゴリズムを構成することによって装置の簡略 化を行なったことなどが特長である。

最後に本ロボットの開発に関連してかずかずの有益 な御助言をいただいた東大産業機械工学科藤井教授, 電子技術総合研究所システム制御研究室佐藤室長, 井 上研究員, ならびに当所沼倉部長に厚く扰礼申し上げ के.

$$
\text { 参考 文 献 }
$$

1）合田：アメリカにお㳊るロボット研究の現状と今後の 問題点, 計測と制御，7-12，23/34 (1968)

2）上滰・佐藤汪か：ETL，ロボット $\mathrm{M}^{\mathrm{K}} \mathrm{I}$ 特集，電子 技術総合研究所亶報, 35-3 (1971)

3) M.Ejiri, T. Uno, H. Yoda, T. Goto, K. Takeyasu: An Intelligent Robot with Cognition and Decision-Making Ability, Second International Joint Conference on Artificial Intelligence, Session 8, 350 (1971)

4) 加藤性か：計算機によって操作される力逆送型人工の 手, 符 1 回穴イオメカニクス・シシポジム, 14 (1970)

5）森・木下：聞值变化法による人工触覚のパターン認識。 生産研究, 21-3,21/22 (1969)

6) 增田・長谷川: 触覚を持っだーボ機構の接触動作, 昭和 15 年霆気四学会連合大会, 2567 (1970)

7）茾上：人工の手の計算機制御，日本機珹学会誌，73$618,946 / 954(1970)$ 